\title{
Effects of Creating an English Language Club on Intermediate Learners' Attitudes and Linguistic Achievement
}

\author{
Ranwa Khorsheed \\ Arab International University, Syria \\ Dareen Assaf \\ Arab International University, Syria \\ Abdulaziz Al-Dammad \\ Foreign Languages Center, Arab International University, Syria
}

\begin{abstract}
This paper discusses the efforts of a group of ELT instructors at a private Syrian university, Arab International University (AIU), to modify students' attitudes towards general English remedial courses at the Foreign Languages Center (FLC) of the university. After analyzing the results of a questionnaire distributed to clarify the students' linguistic needs and assess their motivation, it was concluded that most students preferred interactive language exercises to theoretical text book activities. Thus, the instructors have resorted to practical methods embodied in establishing an English language club that seeks to fulfill students' needs. The club focused on two motivational activities: reading tabloids and making documentary short films. Consequently, regular weekly sessions were organized to hold these activities. All in all, students' attitudes were greatly enhanced and have become more positive. It was also noted that the students have become selfmotivated to the extent of generating new and original ideas that will enrich the English language club at AIU. Furthermore, the students were able to achieve remarkable enhancement on their linguistic skills especially those of reading, writing and speaking in addition to acquiring and improving other personal skills e.g. team work, organizing and planning projects, and communicating ideas via oral presentations.
\end{abstract}

Index Terms - Interactive learning, documentary filming, reading comprehension, team work, language clubs, tabloids

\section{INTRODUCTION}

\section{A. The Importance of Educational Clubs}

Research agrees upon the significance of active learning since it contributes to building the success of college students (Braxton, 2008). Chickering and Gamson (1987) consider active learning as one of the seven principles that constitute good undergraduate education. According to Braxton, Milen and Sullivan (2000), active learning includes different activities such as debates, role-playing, cooperative learning, and discussions. Beyond classrooms, active learning activities can be fully implemented and organized in educational clubs, and these clubs should be "based on student-selected areas of interest" (Casy, 2008, p.285). Astin (1993) posits that getting involved in educational clubs and organizations influences and contributes in the development of college students. Students learn more when they get more involved (Chang, 1990; Huang \&Chang, 2004). Learners who join clubs and organizations have better scores and achieve more than nonmembers on many aspects such as career planning, cultural integration , and academic autonomy (Cooper et al., 1994), additionally, participating in extracurricular activities, that can be practiced in educational clubs fosters learners' competency and interpersonal relationships (Hood, 1984; Martin, 2000). In the findings of their research, Lauren and Granger (2006) suggest that the higher the level of learners' participation is, the more experiences and skills they gain from their college. They suggested that learners should be encouraged to "join clubs and organizations as a way to promote modest gains in development" (p. 178).

\section{B. English Language Clubs as Motivational Tools}

Establishing language clubs is common in university language centers that can be organized in many different ways. Language clubs have one shared characteristic, which is using the language in casual settings and providing learners with an opportunity to practice their language comfortably (Ewens, 2013). Ewens suggests that successful language clubs should be "participant-centered". Other research proposes that when learners share responsibility with other colleagues and teachers and have the opportunity to choose their own learning materials, they become more motivated and engaged (Lewis, 2001). Adopting learner-centered activities is a vital way to motivate and engage language learners 
(Dornyei\&Csizer, 1998). "Differentiation" and allowing learners to choose the materials according to their own interest "is crucial for students' success" that could foster intrinsic motivation (Bell, 2010, p. 41). Language clubs not only motivate high achievers, but also the weak learners. Casey (2008) argues that involving the weak students in the process is "powerfully motivating for adolescents who feel marginalized by the larger literacy community" (p. 291). Another principle for good language clubs according to Ewens (2013) is being fun and providing learners with more freedom. He argues that clubs activities should be flexible, unplanned and interactive, and learners should be free from the constraints of exams, syllables, and rubrics. How language activities is presented affect students' level of motivation and interaction. Language clubs are mainly about holding interactive sessions that include various activities, such as oral presentations, students' intervention and entertainments. Those activities are preferable by language learners (Morell, 2004). Free interactions and learning from each other mistakes are important dimensions of language learning that motivate language learners and encourage them to be more active participants (Lightbown\&Spada, 1993, Davis, 2003; Ghaith, 2003). Hence, "learning clubs have the potential to be a powerful vehicle for motivating engaged and interested learners" along with motivating the "disengaged and frustrated" ones (Casey, 2008, p.11)

\section{METHODOLOGY}

\section{A. Research Rationale and Action Plan}

Considering AIU students' general attitudes and motivation to learn English, a group of EFL instructors at the AIU foreign languages center decided to take action. Thus, they organized a couple of meetings to discuss students' needs and attitudes and plan necessary procedures.

\section{Learners' Needs Analysis}

A comprehensive questionnaire was distributed to a sample of 75 learners registered at the FLC. The aim of the questionnaire was to assess their general attitudes towards the FLC English courses, measure their motivational level and define their linguistic needs.

The questionnaire results.

A total number of 75 intermediate level learners, registered at the FLC at Arab International University, participated in the study. Those students are of different majors; Business Administration, Architecture, and Information Technology Engineering. The majority of the students who took part in the questionnaire acknowledged the importance of English courses as part of the academic curricula and expressed their willingness to improve their linguistic skills. In addition, they confirmed their awareness of the role of English in their future career. From a social and cultural perspective, most of the students stated that learning English would help them meet foreign people and explore western culture and Art. However, about $63 \%$ of the students preferred allocating more time to study other subjects related to their major than allocating it to study English. On the other hand, 50\% of the students have also confessed having a lack of confidence and a feeling of embarrassment when attempting to speak or participate during English classes. When they were also asked about the topics they prefer to read about during reading comprehension classes, the majority expressed their preference of social topics related to their daily lives. It is also worth noting that $45 \%$ of the students expressed their willingness and interest in doing extracurricular activities and joining an English club when available.

\section{B. Establishing the Club}

After analyzing students' linguistic needs and attitudes, a group of FLC instructors held several meetings to discuss the necessary procedures to enhance students' attitudes and motivate them to learn English. Thus, the instructors suggested establishing an English language club that encompasses two main activities. These activities are: Journal (tabloids) based reading comprehension and documentary filming sessions. Each activity would be held in one hour weekly session for three weeks.

\section{Justifying the Selection of the Club's Activities}

Based on the results of the preliminary needs analysis questionnaire, the FLC instructors decided to include journal based reading comprehension sessions. This decision was taken to fulfill the students' needs and preferences of reading real and up to date incidental social topics, which are more related to their daily lives. Furthermore, deciding to hold interactive filming sessions was made with the intention of encouraging the learners to use English to comment on videos recorded by themselves. Since this activity would be partially privately executed, it will enhance the learners' confidence while speaking and participating in class and it will reduce their feeling of embarrassment.

\section{Journal Reading Comprehension Sessions}

The importance of using journals (tabloids) in the English classroom. Tabloids have been used as an up-to-date teaching resource that could easily replace the old typical learning textbooks (Bucura\&Posa, 2011; Sanderson, 1999). It has been proved that tabloids could enhance readership, clarify cultural values, strengthen real life decision making and problem-solving skills, enrich learners' vocabulary, improve their linguistic skills, and cultivate their critical thinking (Aiex, 2001; Bernadowski, 2011; Chandler, 1988; Cheyney, 1992; Daly, 2004; Hess, 1987; Mehta, 2010; Riaz, 2012; Sanderson, 1999; Ping, 2011).

Procedure. This activity was carried out over three weeks, one session each. On the first session, the instructor brought an English journal, The Independent, and introduced its different sections, their purpose and special features. On the second session, the instructor chose an article from the same paper used previously, The Human Hen, and 
explained its contents (title, segments, and photos). The learners were asked to skim the text for repeated words, numbers and specific details e.g. names and places. They were also asked to identify the topic sentence and supporting details in each segment. Then, the instructor wrote four statements on the board and asked the learners to choose the sentence that represents the best summary of the article. After that, the instructor drew the learners' attention to special linguistic aspects of the text that distinguish it from typical reading texts. These aspects are mainly related to the use of active voice, inverted commas, inter-sentence coordination, inter-paragraph coordination, appositive nous phrases, participial phrases, telegraphic structure, and omissions. In the final part of the session, the instructor asked the learners to define typical Art and Artists and compare them to those mentioned in the article (think aloud technique). This helped learners draw connections to the real world (schema theory). On the final session, each pair of learners had to choose and read an article, apply skimming and scanning techniques, and present a written summary to be assessed.

\section{Documentary Filming Sessions}

Video production promotes meaningful learning (Jonassen, Howland, Moore \&Marra, 2003). It also increases students' understanding of the subject matter (Kiili, 2005; Stobel, 2006).

Conducting this activity required about five sessions to complete. Thus, it was held over five weeks, one session each. On the first session, students had an introductory meeting (90 minutes). The researcher asked the learners to produce documentary films about their faculties in English in which they video tape the sections of the faculties and record some interviews with their academic instructors and other students. Every four learners were asked to work together. The researcher also showed the students some sample documentary films about some international universities. Then, two more sessions were held in which students discussed their work and progress, and the difficulties they faced. Other than the classroom meetings, each team created a What'sApp or Facebook group for easier communication, and the researcher was added to these groups. Learners at the end talked about the difficulties they faced, the learning outcomes they gained, their experience of working in groups, and the emotions they experienced while working on the projects. The videos were analyzed and evaluated by the club's supervisors and one expert student who works in the video production field.

\section{RESULTS AND ANALYSIS}

The two designated complementary club activities have been selected to meet learners' needs. They were introduced as scaffolding activities that helped them polish their skills, eliminate their points of weaknesses and support their selfconfidence while using English.

Reflecting back on the outcomes of the club's activities, it could be said that these two activities had significant influence on the learners' practical and linguistic skills. First, holding journal (tabloids) reading comprehension sessions has improved the learners' ability to deal with texts which depict real life situations expressed via real use of English. In addition, these sessions have sharpened the learners' skimming, scanning and summarizing skills. It was noted that the learners were able to comprehend, define and summarize the main ideas of a complete news article. Furthermore, these sessions have offered the learners a chance to get familiarized with different text types and differentiate them from the ones in their learning course books. Second, Filming activities have helped the learners acquire and enhance some important practical skills e.g. teamwork, organization and planning. Furthermore, they have improved the main linguistic skills which are the concern of this paper.

\section{DISCUSSIONS AND CONCLUSIONS}

\section{Learners' Feedback on the Club's Activities}

$83 \%$ of the learners favored this new learning experience. The learners liked the concept of being in charge of their own learning and responsible of the results. Furthermore, $66 \%$ of the learners highly appreciated the freedom granted to them in this activity to design, create, and assess according to their own preferences. Moreover, 55\% of the learners were able to harness their skills, and background knowledge in the production of their short documentary films and journal's summaries. Adding to that, $60 \%$ of the learners confessed enjoying teamwork and collaboration in this activity. It is also worth mentioning that $53 \%$ of the learners highly valued the sense of commitment they had to put forth into their work.

\section{CONCLUSION}

Establishing an English language club at the Arab International University was of highly influential effects on the participants' attitudes and motivation to learn English. It gave them a chance to view English in a lively vivid state as they proceeded with their interactive learning sessions. It was an opportunity to escape the rigid frame of typical English courses. The club has even encouraged students to keep track of their original remedial English courses and become regular attendees. The whole idea of the club infused the learners with enthusiasm, anticipation and enjoyment. The club has also helped in increasing the learners' awareness to the vital role of English in their lives and future careers. Those students now appreciate learning the language and make use of all the information they receive. Thus, the mission of the club has been accomplished. 


\section{REFERENCES}

[1] Aiex, N.K. (2000). Newspapers as a teaching and communication resource. Online ESL article. ERIC clearing house on reading English and communication. Bloomington. IN.

[2] Astin, A. W. (1993). What matters in college? Four critical years revisited. San Francisco: Jossey-Bass.

[3] Antepara, R. (2003). Using news stories in the ESL classroom. The Internet TESLJournal, 9 (12). 220-231

[4] Babalola, E.A. (2002). Newspapers as instruments for building literate communities: The Nigerian experience. Nordic journal of African studies 11 (3), 403-410.

[5] Bankole, O.M \&Babalola, S.O. (2011). Use of newspapers by students of OlabisiOnabanjo University, Ago-Iwoye, Ogun State, Nigeria. Library of philosophy and practice (e-journal). Vol. 1, No 1. Paper 462. University of Nebraska- Lincoln.

[6] Bell, S. (2010). Project Based Learning for the $21^{\text {st }}$ Century: Skills for the Future. The Clearing House, 83(2), 39-43.

[7] Bernadowski, C. (2011). A good read, literacy strategies with newspapers. (Newspaper association of America) foundation. Senior vice president and secretary/treasurer: Margaret Vassilikos. Arlington.

[8] Brown, A.L., \&Palincsar, A.S. (1981). A guided cooperative learning and individual knowledge acquisition. In L. Resnick (Ed.), Knowing, learning and instruction: Essays in honor of Robert Glaser.

[9] Bonwell, C. C., \&Eison, J. A. (1991). Active Learning: Creating Excitement in the Classroom. ASHE-ERIC Higher Education Report, no. 1. San Francisco: Jossey Bass.

[10] Braxton, J. M., Milem, J. F., \& Sullivan, A. S. (2000). The Influence of Active Learning on the College Student Departure Process: Toward a Revision of Tinto's Theory. Journal of Higher Education, 71(5), 569-590.

[11] Braxton, J. M. (2008). Toward a Theory of Faculty Professional Choice in Teaching That Fosters College Student Success. In J. C. Smart (ed.), Higher Education: Handbook of Theory and Research vol. 23, pp. 181-207. Dordrecht: Springer.

[12] Burn, A., Brindley, S., Durran, J., Kelsall, C., Sweetlove, J., \&Tuohey, C. (2001). The rush of images: A research report into digital editing and the moving image. English in Education, 35(2), 34-47.

[13] Chickering, A. W., \&Gamson, Z. F. (1987). Seven Principles for Good Practice. AAHE Bulletin, 39, 3-7.

[14] Chang, S. M. (1990). The impacts of colleges on students [In Chinese]. Taipei, Taiwan: Teacher Chang Culture Press.

[15] Chandler, C.E. (1988). Use the news: press to read: Literacy now! Journal of Reading, 31 (8), 746-748.

[16] Cheyney, A.B. (1992). Teaching reading skills through the newspaper. Newark: International Reading Association.

[17] Cooper, D. L., Healy, M. A., \& Simpson, J. (1994). Student development through involvement: Specific changes over time. Journal of College Student Development, 35, 98-102.

[18] Casey, H. (2008). Engaging the Disengaged: Using Learning Clubs to Motivate Struggling Adolescent Readers and Writers. Journal of Adolescent \& Adult Literacy, 52(4), pp.284-294.

[19] Daly, B. (2004). Facilitating discussions of newspaper articles in the ESL/EFL classroom. The internet TESL Journal, $x$ (7). $134-150$

[20] Davis, A. (2003). Teachers' and students' beliefs regarding aspects of language learning. Evaluation and Research in Education, 17(4), 207 - 216. doi:10.1080/09500790308668303, http://dx.doi.org/ 10.1080/09500790308668303.

[21] Dornyei, Z. \&Csizer, K. (1998). Ten Commandments for motivating language learners: Results of an empirical study. Language Teaching Research, 2(3), $203 \quad-\quad 229 . \quad$ doi:10.1191/136216898668159830, http://dx.doi.org/10.1191/136216898668159830.

[22] Ewens, T. (2013). English Clubs. Retrieved 26 August 2017, from https://www.teachingenglish.org.uk/article/english-clubs.

[23] Echevarria, J., Vogt,M., \& Short, D.J. (2008). Making content comprehensible for English learners: The Stop model (3 ${ }^{\text {rd }}$ ed). Boston, MA. Pearson.

[24] Elmadwi, M.H. (2014). A study of the significance of using newspapers as an instrument to develop reading and comprehension skills for learning of English as a second language. International Journal of English language, literature and humanities.Vol. 1, No5. 110-140.

[25] Foubert, J \& Grainger, L. (2006). Effects of Involvement in Clubs and Organizations on the Psychosocial Development of First-Year and Senior College Students. NASPA, 43(1). 412-420.

[26] Gibson, J. J. (1986). The ecological approach to visual perception. Mahwah, NJ: Lawrence Erlbaum Associates.

[27] Grundy, P. (1994). Newspapers. Issues in applied linguistics. University of California, Los Angeles.

[28] Ghaith, Gh. (2003). The relationship between forms of instruction, achievement and perceptions of classroom climate. Educational Research, 45 (1), 83 - 93. doi:10.1080/0013188032000086145, http://dx.doi.org/10.1080/0013188032000086145.

[29] Hess, N. (1987). Newspapers in the English classroom: Stressing sociolinguistic communicative competence in an authentic frame work. English teachers' Journal, 35, 70- 71.

[30] Huang, Y. R., \& Chang, S. M. (2004). Academic and curricular involvement: Their relationship and the best combinations for student growth. Journal of College Student Development, 45(4), 391-406.

[31] Hofer, M., \& Owings-Swan, K. (2005). Digital moviemaking - the harmonization of technology, pedagogy and content. International Journal of Technology in Teaching and Learning, 1(2), 102-110.

[32] Hoffenberg, H., \& Handler, M. (2001). Digital video goes to school. Learning and Leading with Technology, 29(2), 10-15.

[33] Hood, A. B. (1984). Student development: Does participation affect growth? Bulletin of the Association of College UnionsInternational, 54, 16-19.

[34] Johnson, R.T. (1986). Comparison of computer-assisted cooperative, competitive, and individualistic learning. American Educational Research Journal, 23(3), 382-392.

[35] Johnson, D.W., \& Johnson, R.T. (1989). Social skills for successful group work. Educational Leadership, 47(4), $29-33$.

[36] Jonassen, D. H., Howland, J., Moore, J., \& Marra, M. (2003). Learning to solve problems with technology: A constructivist perspective. Upper Saddle River, NJ: Merrill Prentice Hall.

[37] Kenji, K. (1995). Teaching English through newspapers. English literacy society of Doshisha University.

[38] Kim, I. (2005). The headlines and sentence structure in English language newspapers. Educational research. USA. 4 (15), 4567. 
[39] Kearney, M., \& Schuck, S. (2003). Authentic learning through the use of digital video, in W. Au and B. White (Eds.) Proceedings of the Australian Computers in Education Conference. [CD-ROM].

[40] Kiili, K. (2005). Participatory multimedia learning: Engaging learners. Australasian Journal of Educational Technology, 21(3), 303-322.

[41] Koehler, M. \& Mishra, P. (2005). Teachers Learning Technology by Design. Journal of Computing in Teacher Education, 21(3), 320-330.

[42] Lewis, C. (2001). Literary practices as social acts: Power, status, and cultural norms in the classroom. Mahwah, NJ: Erlbaum.

[43] Lightbown, P.M. \&Spada, N. (1993). How languages are learned. Oxford: Oxford University Press.

[44] Mehata, N.K. (2010). English newspapers: Exploring innovative methodological paradigm. A study into classroom dynamics. Romanian Journal of education. Vol.1, No 1, pp. 55-60.

[45] Martin, L. M. (2000). The relationship of college experiences to psychosocial outcomes in students. Journal of College StudentDevelopment, 41, 294-303.

[46] Morell, T. (2004). Interactive lecture discourse for university EFL students. English for Specific Purposes, 23,325 -338. doi:10.1016/S0889-4906(03)00029-2, http://dx.doi.org/ 10.1016/S0889-4906(03)00029-2.

[47] McCune, V. (2004). Development of first-year students' conceptions of essay writing. Higher Education, 47, 257 -282.

[48] Norman, D. (1993). Things that make us smart: Defending human attributes in the age of the machine. New York: AddisonWesley.

[49] New, J. (2006). Film school: The silver screen inspires young minds to think big. Edutopia, 1(9), 20-23.

[50] Ping, W. (2011). Exploring innovative activities in using news stories to teach advanced Chinese learners English in a multimedia way. Journal of English and Literature. 2(5), P. 103-114.

[51] Riaz, M. (2013). Task based language learning in English for specific purposes: An exploration in to the use of newspapers for teaching English as a second language to engineering students in Pakistan. The journal of teaching English for specific and academic purposes. Vol. 2, No 4, pp.685-696.

[52] Ryan, S. (2002). Digital video: Using technology to improve learner motivation. Modern English Teacher, 11(2), 72-75.

[53] Reid, M., Burn, A., \& Parker, D. (2002). Evaluation report of the Becta digital video pilot project. Coventry: Becta.

[54] Sanderson, P. (1999). Using Newspapers in the Classroom. Cambridge University Press, United Kingdom.

[55] Strobel, J. (2006). Participatory design strategies for eLearning: A design-based research approach in the field of educational technology. In J. Multisilta\& H. Haaparanta (Eds.), Proceedings of the Workshop on Human Centered Technology HCT06 (pp. 187-195). Tampere University of Technology, Pori. Publication 6.

[56] Tafani, V. (2009). Teaching English through Mass Media. ActaDidacticaNapocensia. 2 (1), P. 84-101.

[57] Worthy, J. \& Broaddus, K. (2002). Fluency beyond the primary grade: from group performance to silent independent reading. The reading teacher, 55 (4), 334-43.

Ranwa Khorsheed. Born in Damascus, Syria, May, 1984. Studied English language and literature at Damascus University. Got a Master degree in general linguistics, Damascus University, 2014. She worked for private language institutes. Also worked as an English language instructor at Damascus University. (2015-Present) working for the Syrian Virtual University and the Arab international University, Foreign Languages Center in Damascus, Syria.

Dareen Assaf. Born in Damascus, Syria, February, 1984. Studied English Language and Literature at Damascus University. Got a Master degree in Education, Exeter University, UK, 2008. From 2009 to 2010, she worked as a lecturer at The Higher Institute for Teaching Languages at Tishreen State University. (2010- 2012) worked as a lecturer at Al Kalamoon University (UOK), English Department. (2012 to 2016) worked as a lecturer and the coordinator of the English Program at Syrian Private University (SPU). (2012 to Present) working as a Lecturer at Arab International University (AIU), Foreign Languages Center in Damascus, Syria.

Abdulaziz Al-Dammad. Born in Daraa, Syria. Studied English Language and Literature at Damascus University. Got a Master of Science (MSc) in Conference Interpreting and Translation, Heriot-Watt University, UK. He worked as a teacher of English in the Kuwaiti ministry of education. Worked at the Syrian Virtual University. From 2009 -present working as a senior lecturer at the Higher Inistitute for Interpreting and Translation at Damascus University. From (2009- present) working for the Arab International University, Head of the Foreign Languages Center in Damascus, Syria. 